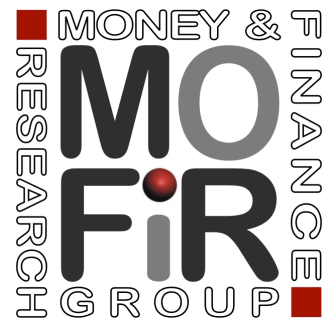

\title{
INTERNATIONALIZATION CHOICES: AN ORDERED PROBIT ANALYSIS AT INDUSTRY-LEVEL
}

Filomena Pietrovito Alberto Franco Pozzolo Luca Salvatici

Working paper no. 77

January 2013 


\title{
Internationalization choices: an ordered probit analysis at industry-level
}

\author{
Filomena Pietrovito - Alberto Franco Pozzolo - Luca Salvatici
}

\begin{abstract}
Trade theory traces back different patterns of internationalization to heterogeneity between firms, measured both through differences in productivity levels and size. In this paper we analyze the link between heterogeneity within sectors and internationalization choices, namely trade and foreign direct investments (FDI) for a large sample of countries and industries between 1994 and 2004. The focus of our paper is on the role played by average productivity level and the distribution of firms by size in explaining differences across sectors and countries in the extensive margin of internationalization (i.e., the number of foreign nations where firms from a given sector and country have expanded abroad). By performing an ordered probit analysis, and controlling for other factors affecting the patterns of internationalization, we confirm that industries with higher productivity levels and with a distribution of firms shifted toward large firms are more prone to internationalize in foreign markets through both trade and FDI. Moreover, the relative impact of average productivity and firm size on FDI is larger than that on trade. These results are robust to different measures of productivity and the distribution of firms.
\end{abstract}

Keywords: exports, foreign direct investments, mergers and acquisitions, productivity, distribution of firms, ordered probit.

JEL classification: D24, F10, F14, F20, F23

\author{
F. Pietrovito (corresponding author) \\ Università degli Studi del Molise, Dipartimento di Economia, Gestione, Società e Istituzioni \\ II Edificio Polifunzionale \\ Via F. de Sanctis, snc \\ 86100 Campobasso \\ e-mail: filomena.pietrovito@unimol.it
}

\author{
A. F. Pozzolo \\ Università degli Studi del Molise, Centro Studi Luca D'Agliano, MoFiR and CASMEF \\ Università degli Studi del Molise, Dipartimento di Economia, Gestione, Società e Istituzioni \\ II Edificio Polifunzionale \\ Via F. de Sanctis, snc \\ 86100 Campobasso \\ E-mail:pozzolo@unimol.it \\ L. Salvatici \\ Università degli Studi Roma Tre, Dipartimento di Economia \\ Via Silvio D'Amico, 77 \\ 00145 Roma \\ E-mail: lsalvatici@uniroma3.it
}




\section{Introduction}

Firms in a given sector can serve foreign consumers through two main channels: $(i)$ producing at home and then exporting and (ii) setting or acquiring foreign establishments to produce abroad. The trade and international business research literature has shown that the choice of the foreign entry mode hinges on characteristics of products, firms, sectors and countries (Barba Navaretti and Venables 2004; Slangen et al. 2011).

While there is a long tradition of studies on the factors underlying specific patterns of foreign expansion through trade or foreign direct investments (FDI), ${ }^{1}$ the literature focusing on different forms of internationalization is relatively more recent. In the traditional proximity-concentration trade-off literature, a well-accepted result is that FDI become more convenient than exports as both the size of the foreign market and the costs of exporting increase, and less convenient as the costs of setting up foreign production grow (Brainard 1993, 1997; Yeaple 2003). ${ }^{2}$ As pointed out by Brainard (1993), firms can be expected to invest abroad when the gains from avoiding transport and tariff costs outbalance the costs of maintaining capacity in multiple markets.

This literature does not predict which firms in each sector become international (Head and Ries 2003). More recent contributions, starting from the seminal paper by Melitz (2003), address this issue taking into account the role of heterogeneities in firm-level productivity. Building on this theoretical framework, Helpman et al. (2004) expand the set of internationalization choices by including FDI in addition to trade. This new setting typically leads to the following ranking in terms of productivity and size: multinational firms outperform exporters, which in turn outperform domestic firms. But the empirical validation of the theoretical framework of Melitz (2003) and Helpman et al. (2004) is not fully satisfactory for two main reasons. First, the impact of the two sources of firms heterogeneity, namely productivity and size, are not clearly distinguished. Second, most analyses focus on single countries, the few for which data on export and FDI at a disaggregated level are more readily available. $^{3}$

In this paper, we analyse the relationship between country-sector characteristics and internationalization strategies (i.e., export and FDI) for a large sample of countries, with the aim of

\footnotetext{
${ }^{1}$ For a recent survey of this literature see Greenaway and Kneller (2007).

${ }^{2}$ Another strand of the literature focuses on the distinction between horizontal and vertical FDI (see, e.g., Carr et al. 2001). However, this issue is out of the scope of our analysis.

${ }^{3}$ An exception is provided by Pietrovito et al. (2013). Using a large dataset including a large sample of countries at different level of development, they are able to confirm that sectors with a higher number of large firms and a high productivity level are associated with a stronger incidence of FDIs relative to trade.
} 
identifying sectors and countries more prone to expand abroad. More specifically, we enlarge previous empirical analyses building a large dataset including 24 origin countries, 91 destination countries and 57 manufacturing industries between 1994 and 2004.

We disentangle the effect of productivity from that of firm size testing two separate hypotheses on the relationship between industry heterogeneity and internationalization: $(i)$ that sectors featuring higher productivity levels are more likely to internationalize through exports and/or FDIs; and (ii) that sectors featuring a size distribution shifted toward large firms are also likely to internationalize through exports and/or FDIs. To this end, we use an ordered probit model to assess the impact of several covariates at sector level on a discrete foreign expansion index ranging from 0 to 2 according to whether: sectors serve uniquely the domestic market, export only, export and perform FDI as well. ${ }^{4}$ Results confirm that more productive sectors and sectors with a distribution of firms shifted toward large firms are more prone to foreign expansion, through both trade and FDI.

Our analysis contributes to the literature explaining the nature of the internationalization processes, along three dimensions. First, we expand the span of variables considering separately the productivity level and the distribution of firms by size in each sector. This marks a departure from previous contributions which have either focused on the former or on the latter type of variables. ${ }^{5}$ Second, we use bilateral flows of trade and FDI at sector level for a large sample including both developed and least-developed countries. This allows us to simultaneously measure the impact on the internationalization index of several country-level and sector-level factors, alongside with productivity and the distribution of firms by size, taking into account potential heterogeneities within as well as across countries. ${ }^{6}$ Moreover, our dataset allows the estimation of the effects of average productivity and firms size controlling for all country and sector invariant unobserved characteristics. This reduces the risk of the possible reverse causality problems, that would be present if countries and/or sectors that are intrinsically more internationalized turned also out to be the most productive and/or those with firms of

\footnotetext{
${ }^{4}$ Whereas in a linear regression, a sector with an index equal to 2 would be twice as internationalized as one with an index equal to 1 , in the ordered probit model, no such presumption of cardinality is made: a value of 2 simply indicates more internationalization than a value of 1 .

${ }^{5}$ In the literature, the distinction between the impact of firm size and firm productivity in the modes of export is blurred, due to the fact that firm size is typically assumed to depend on the level of productivity, that in turn follows a Pareto distribution (see, e.g., Helpman et al. 2004). However, if firm size followed a different distribution across sectors, the relationship between dispersion and the number of highly productive (large) firms could be non-linear (or even nonmonotonic).

6 To disentangle potential differences between groups of countries, we also provide evidence on the patterns of internationalization depending on the level of country development.
} 
larger size. ${ }^{7}$ It also reduces the risk of possible endogeneity problems if an omitted country or sector characteristic caused firms to be at the same more productive and/or larger, and more international. Third, from a methodological point of view, we analyze the complexity of the internationalization process in a multinomial framework. Adopting the view that the internationalization process is complex and cumulative, since it is based on accumulating experience and higher commitment, we use an ordered probit model to analyze the determinants of different internationalization involvements (domestic - i.e., no internationalization at all, only exports and both exports and FDI).

The paper is organized as follows. Section 2 briefly discusses the theoretical and empirical background and the hypotheses to be tested. Section 3 presents the empirical model. Section 4 describes the data used in the analysis. The main results of the analysis are presented in Section 5, along with a number of robustness checks. Section 6 draws some conclusions.

\section{Previous literature and testable hypothesis}

Two related aspects of the role of firms heterogeneity in the choice of the mode of internationalization have been analyzed in the literature: the impact on the value of existing exports or investments to the same destination(s) - the intensive margin - and the impact on the number of export items or foreign countries where firms export or set up a foreign subsidiary - the extensive margin.

The most influential theoretical model to study the choice between internationalization through trade or FDI is that of Helpman et al. (2004). The analytical framework focuses on the intensive margin and builds on the seminal paper by Melitz (2003), where monopolistically competitive firms draw different levels of productivity from an exogenous distribution and find internationalization profitable only if they are productive enough to reach the scale that is necessary to sustain the fixed costs of exporting. A key feature of this model is that firm productivity maps exactly into firm size, and therefore exporting firms are at the same time more productive and larger. Making the additional assumption that the fixed costs of setting up a foreign subsidiary are higher than those of exporting, Helpman et al. (2004) show that a higher within-industry heterogeneity in firm sales is associated with a higher incidence of sales by foreign affiliates relative to exports, because greater dispersion implies a larger share of firms with a sufficiently high level of productivity to find it profitable to invest abroad.

\footnotetext{
${ }^{7}$ As highlighted by several studies (Bernard et al. 1995; Bernard and Jensen 2004; Castellani and Zanfei 2007), not only firms self-select into internationalization modes, with more productive and larger firms becoming more involved in international activities, but their level of productivity and size could also be influenced by internationalization involvement. For a meta-analysis of this literature, see Martins and Yang (2009).
} 
Using data on exports and foreign subsidiaries' sales of US manufacturing firms in 30 countries and 52 industries, they find that a wider dispersion of firms size (and therefore of productivity) within each sector is associated with a larger incidence of foreign affiliates' sales relative to exports. ${ }^{8}$ Additional empirical evidence, surveyed by Bernard et al. (2007) and Greenaway and Kneller (2007), confirms the theoretical hypothesis that firms self-select into internationalization strategies depending on their productivity level and size. ${ }^{9}$

The literature analysing the extensive margin of trade and FDI is mostly empirical. In the real world, the choice of a firm to enter or not a given foreign country ranges from "no internationalisation" to all possible combinations of the available set of internationalisation modes. In the empirical literature, these options are analysed estimating the pattern of internationalization conditional on several firms, industry and country characteristics, by means of either non-ordered or ordered multiple choice models.

In the framework of non-ordered models (bivariate probit, multinomial logit and probit), choices are typically exhaustive and mutually exclusive, and each firm is assumed to choose the strategy that maximises its profit function. Several contributions in the literature use non-ordered models to analyse internationalization choices in specific countries. To estimate the productivity effects on the probability of investing abroad or exporting, Oberhofer and Pfaffermayr (2012) use a bivariate probit model that allows for both modes: the number of employees as a measure of firm size and productivity of companies increase the probability of both strategies, but the effect is larger for the probability of investing abroad. Similarly, Kimura and Kiyota (2006), by adopting a probit model with random effects, find that the most productive firms are those that engage both in FDI and in export.

Concerning the multinomial logit approach, Bougheas and Görg (2008) estimate the probability that Irish firms choose one of the modes of internationalization, conditional on a number of plant characteristics (including productivity). They find that $(i)$ exporters are more productive than nonexporter and (ii) exporting firms that also invest abroad are more productive than firms that only export. Using the same methodology, Benfratello and Razzolini (2009) confirm the same ranking of productivity for a sample of 4,000 Italian firms.

\footnotetext{
${ }^{8}$ Similarly, Oldenski (2010) extends the analysis of Helpman et al. (2004) showing that greater firm-level heterogeneity in firm size significantly increases FDI relative to exports also in service industries.

${ }^{9}$ A partly contrasting result is that of Todo (2011) who, allowing firm heterogeneity in unobserved characteristics by estimating a multinomial logit model with random intercepts and random coefficients (a mixed logit model), finds a small economic impact of productivity on the probability that a firm exports or invests abroad for Japanese firms.
} 
Since the multinomial logit models is subject to the constraint of the independence of irrelevant alternatives, some papers in the related literature estimate a multinomial probit model. For example, Engel et al. (2009) analyse the relationship between firm-specific characteristics and the entry and exit pattern in foreign markets for the two main modes of internationalization, namely export and FDI. For a sample of French firms, they find that high productivity firms have a significantly higher propensity to invest abroad than low productivity firms. In such models, choices are exhaustive and mutually exclusive and the firm chooses only the alternative that maximises the profit function.

Unfortunately, multiple-choice models become cumbersome for a large number of internationalisation forms because the different forms can be combined and each combination defines a choice. For this reason, Calia and Ferrante (2010) use a multivariate probit model to estimate the relevant associations between different internationalisation patterns and variables describing firm characteristics. In particular, they study Italian firms considering a wide range of internationalisation forms, including offshoring of production and outsourcing of services abroad, as well as non-equity forms, such as commercial penetration operations and agreements, in addition to the exports and FDI modes. Regarding productivity, their results suggest that it affects the choice to stay domestic or to have international activities, but not the choice among different internationalization modes.

To the best of our knowledge, in the framework of ordered models only Basile et al. (2003), focusing on Italian manufacturing firms, adopt an ordered probit to investigate the determinants of foreign expansion through exports and investment. In practice, they postulate that a higher internationalization level implies a greater cumulative commitment to foreign markets and a better firm's position in those markets. Their results suggest that firm size, the relationships with other firms, innovation and geographic location are very important determinants of variations in the foreign expansion index across firms in different points in time. However, their analysis does not include any measure of productivity, which is instead one of the crucial explanatory variables of our paper.

Following Helpman et al. (2004), in most of the literature cited above, firm size is a function of its productivity, and therefore the impacts of the two characteristics are not separately evaluated. On the contrary, in our empirical framework we choose to disentangle the effect of firms productivity from that of firm size, testing two separate hypotheses:

Hypothesis 1: a higher level of productivity in a given sector of a given country is associated with a higher level of foreign expansion along the extensive margin, with a stronger effect on FDI than on exports. 
Hypothesis 2: a firm distribution shifted toward large firms in a given sector of a given country is associated with higher level of foreign expansion along the extensive margin, with a stronger effect on FDI than on exports.

These hypotheses state that sectors with higher productivity levels and firm distribution shifted toward large firms, cumulate different and more demanding forms of internationalization to enlarge their involvement. As a matter of fact, when firms are able to assume higher risks associated with international activities, they enter the international market with forms requiring higher experience, investments and commitment.

\section{Empirical methodology}

To test the two hypotheses put forward in the previous section, we design a set of regression models. These models are based on the estimation of an ordered discrete choice model to evaluate how countries' and sectors' characteristics affect the likelihood of different international involvement. In general, in a $J$-choice ordered probit model $y$ is an ordered response where the values we assign to each outcome represent a specific order along a continuum, but not the magnitude of difference between the options. In our specification, $y$ is an indicator of international involvement at sector level ranging between zero and 2, with: $y=0$ for sectors that are not internationalized at all ("domestic"), $y=1$ for sectors that internationalize only through trade ("export") and $y=2$ for sectors that have both trade and FDI ("export and FDI"). The fact that 2 indicates a higher international involvement than 1 (and 0 ) conveys useful information, even though the index itself has only an ordinal meaning.

For such an ordinal dependent variable, using multinomial probit or logit would not be efficient, because these models would mis-specify the data-generating process in assuming that there is no order in the different categories that the dependent variable can take. OLS regression estimation would also be inappropriate, since it would consider the difference in the dependent variable between a 0 and a 1 as equivalent to the difference between a 1 and a 2 . Greene (2008) summarizes the previous remarks pointing out that when "the outcome is discrete, the multinomial logit or probit model would fail to account for the ordinal nature of the dependent variable. Ordinary regression analysis would err in the opposite direction, however" (Greene 2008, p. 831).

The ordered probit model for $y$ can be derived from a latent or unobserved continuous variable, $y^{*}$, related to a set of explanatory variables according to a standard linear model: 
$y^{*}=\beta_{0}+\beta_{1} x_{1}+\beta_{2} x_{2}+\ldots .+\beta_{K} x_{K}+\varepsilon$

where, $x_{1, \ldots, K}$ are the explanatory variables, which may include sector and country characteristics influencing the probability of different internationalization involvements, $\beta_{1 \ldots k}$ are the associated parameters, and $\varepsilon$ is a random error term drawn from a standardized normal distribution. Although $y^{*}$ is unobserved, $y$ is observed and related to $y^{*}$ by the following relationship:

$y=0 \quad$ if $y^{*} \leq \alpha_{1}$

$y=1$ if $\alpha_{1}<y^{*} \leq \alpha_{2}$

$y=2$ if $y^{*}>\alpha_{2}$

where, $\alpha_{1}<\alpha_{2}$ are the unobserved cut points identifying the boundaries between the different levels of international involvement. Therefore, given the standard normal assumption for the error term, we can derive each response probability of observing a sector as being "domestic" (i.e., the dependent variable $y$ taking the value of 0 ) as:

$$
\begin{aligned}
\operatorname{Pr}[y & =0]=\operatorname{Pr}\left[y^{*} \leq \alpha_{1}\right] \\
& =\operatorname{Pr}\left[\beta_{0}+\beta_{1} x_{1}+\beta_{2} x_{2}+\ldots .+\beta_{K} x_{K}+\varepsilon \leq \alpha_{1}\right] \\
& =\operatorname{Pr}\left[\varepsilon \leq \alpha_{1}-\left(\beta_{0}+\beta_{1} x_{1}+\beta_{2} x_{2}+\ldots .+\beta_{K} x_{K}\right)\right] \\
& =\Phi\left(\alpha_{1}-\left(\beta_{0}+\beta_{1} x_{1}+\beta_{2} x_{2}+\ldots .+\beta_{K} x_{K}\right)\right) \\
& =\Phi\left(\alpha_{1}-\mathbf{x} \boldsymbol{\beta}\right)
\end{aligned}
$$

where $\boldsymbol{\Phi}($.) is the standard normal distribution function. Similarly, we can obtain the probability of $y=$ 1 and $y=2$ in the following way:

$$
\begin{aligned}
& \operatorname{Pr}[y=1]=\operatorname{Pr}\left[\alpha_{1}<y^{*} \leq \alpha_{2}\right]=\Phi\left(\alpha_{2}-\mathbf{x} \boldsymbol{\beta}\right)-\Phi\left(\alpha_{1}-\mathbf{x} \boldsymbol{\beta}\right) \\
& \operatorname{Pr}[y=2]=\operatorname{Pr}\left[y^{*}>\alpha_{2}\right]=1-\Phi\left(\alpha_{2}-\mathbf{x} \boldsymbol{\beta}\right)
\end{aligned}
$$

The $\beta$ parameters together with the threshold levels on the latent variable that characterize the transition from one observed categorical response to the next (cut points $\alpha$ ) can be obtained by maximum likelihood estimation.

In our empirical setting, the main specification adopted in the empirical analysis is the following:

$$
\begin{aligned}
y_{i j}^{h} & =\beta_{0}+\beta_{1} \text { TFP }_{i}^{h}+\beta_{2} \text { Number_of_large_firms }{ }_{i}^{h}+\beta_{3} \mathbf{Z}_{i}^{h}+\beta_{4} \mathbf{T}_{i j}+\beta_{5} \mathbf{V}_{i j}^{h} \\
& +\beta_{6} \mathbf{D U}_{i}+\beta_{7} \mathbf{D} \mathbf{U}_{j}+\beta_{8} \mathbf{D U}^{h}+\varepsilon_{i j}^{h}
\end{aligned}
$$


where $y_{i j}^{h}$ is the ordered dependent variable that takes the value 0 for sectors of country $i$ not exporting to country $j$, the value 1 for sectors of country $i$ presenting exports but not FDI to country $j$, and the value 2 for sectors of country $i$ featuring both exports and FDI ${ }^{10} \operatorname{TFP}^{h}{ }_{i}$ is the average productivity level in sector $h$ in country $i$; Number_of_large firms ${ }_{i}{ }_{i}$ is the number of firms of sector $h$ in country $i$ in the $10^{\text {th }}$ decile of the world firms distribution of total sales in sector $h ; \mathrm{Z}_{i}^{h}$ is a set of control variables for sector $h$ of country $i$ (i.e., capital and technological intensity); $\mathrm{T}_{i j}$ is the set of control variables describing the bilateral relationship between countries $i$ and $j$ (e.g., distance, islands, common language and common religion); $\mathrm{X}_{i j}^{h}$ is the set of control variables describing the bilateral relationship between countries $i$ and $j$ in a given sector $h$ (i.e., tariffs, number of common partners in trade or FDI); and DU, $\mathrm{DU}_{j}$ and $\mathrm{DU}^{h}$ are three sets of dummies controlling for unobserved common characteristics at the level of the origin country $i$, the destination country $j$, and the sector $h$.

We control for country and industry invariant characteristics by introducing fixed effects for origin countries, destination countries and sector of economic activity. In addition, we include a set of control variables that are based on characteristics specific of each industry in each country, on country pairs characteristics, and on country pairs/industry characteristics. This specification allows to control for potential effects of country and sector specific characteristics that might contemporaneously enhance the international activity as well as the average productivity and the distribution of firms.

According to the two main assumptions presented in the previous section, we expect the estimated coefficients of our key independent variables to be positive and statistically significant, after controlling for other industry and country characteristics. In general, increasing one of the independent variable, while holding coefficients and cut points constant, is equivalent to shifting the distribution to the right. The effect of this shift is unambiguously to shift some mass out of the leftmost cell (Greene 2008, p. 833). Accordingly, finding a positive coefficient for an independent variable implies that the change of the probability of being a "domestic" sector $(\operatorname{Pr}[y=0])$ moves in the opposite direction with respect to $\beta_{1}$ and $\beta_{2}$, while the change of the probability mass of being an "export and FDI" sector $(\operatorname{Pr}[y$ =2]) move in the same direction. However, what happens to the middle category $(\operatorname{Pr}[y=1])$ is ambiguous, because the probability mass moving from "domestic" to the "export" can be either larger or smaller than that moving from "export" to "export and FDI".

\footnotetext{
${ }^{10}$ The very few cases of sectors that have FDI but no trade are dropped from the sample.
} 


\section{Data and sample ${ }^{11}$}

\subsection{Dependent variable}

To construct the dependent variable for the ordered model, we need data on both exports and FDI. The main statistical source of data on exports is the database UN Comtrade, managed by the statistical division of the United Nations, that reports data on the bilateral flows in several industrial sectors. In particular, it contains annual international trade statistics, detailed by commodity and partner country, for a very large set of countries. Commodities are classified according to different recognized classifications, such as the standard international trade classification (SITC) and the harmonized commodity description and coding system (HS). We use the international standard industry classification (ISIC), Revision 3, at 4-digits level to be able to concord data on export with other data used in the empirical analysis.

Much less information is available on FDI, especially at the bilateral and sector levels. To overcome these shortcomings, we use information on Mergers and Acquisitions (M\&A) as a proxy for FDI. While this is a limitation of our analysis, we believe that it is unlikely to affect the qualitative results, because cross-border M\&A are by and large the most widely used mode of operating a foreign firm (Herger et al. 2008). Data on M\&A are sourced from SDC Platinum Global mergers and acquisitions, a database provided by Thomson financial securities data that records all deals involving a change in ownership of at least 5\% of total equity and exceeding 1 million US dollar. The Thomson dataset allows to analyze M\&A for a large range of countries and years. It records two related aspects of cross-border acquisitions: the number of acquisitions and their value. ${ }^{12}$ A common choice in the literature on M\&A, is to consider disclosed and complete deals for which the value of the transaction is available. This choice allows us to construct a more reliable database. The database also contains information on target and acquirer profiles, such as industry classification, based on the primary activity and location, that are used in our empirical analysis. In particular, we identify cross-border deals in manufacturing standard industry classification (SIC) codes at 4-digits level. ${ }^{13}$

\footnotetext{
${ }^{11}$ Table 1 lists all variables used in the analysis and their sources.

12 The main sources of information of data on M\&A are financial newspapers and specialized agencies like Bloomberg and Reuters. It should be kept in mind that until the mid-1980s Thomson focused very much on M\&A for the USA only, and it is only for about the last 20 years that (systematic) M\&A data gathering took place for other countries (Brakman et al. 2005).

13 Domestic M\&A, i.e., acquisitions with acquirer and target located in the same country, could still provide access to foreign markets if the target firm is active abroad or if the acquirer is controlled by a foreign firm. However, in the former
} 
Table 1 - Variables description and sources

\begin{tabular}{|c|c|}
\hline Definition & Description and Source \\
\hline \multicolumn{2}{|r|}{ Dependent variable } \\
\hline$y$ & $\begin{array}{l}\text { Categorical variable taking the value of zero if sector } h \text { in country } i \text { neither exports } \\
\text { nor invests in country } j \text {, the value of } 1 \text { if sector } h \text { in country } i \text { only exports in } \\
\text { country } j \text { and the value of } 2 \text { if sector } h \text { in country } i \text { both exports and invests in } \\
\text { country } j \text {. } \\
\text { Source: UN Comtrade for exports and SDC Platinum for FDI }\end{array}$ \\
\hline \multicolumn{2}{|r|}{ Key independent variables } \\
\hline$T F P^{a}$ & $\begin{array}{l}\text { Average level of total factor productivity in sector } h \text { in country } i \text {. } \\
\text { Source: UNIDO (Indstat } 4,2008 \text { version) }\end{array}$ \\
\hline Labour productivity ${ }^{a}$ & $\begin{array}{l}\text { Ratio between value added and number of employees in sector } h \text { in country } i \text {. } \\
\text { Source: UNIDO (Indstat } 4,2008 \text { version) }\end{array}$ \\
\hline Num. of large firms $\left(9^{\text {th }} \text { decile }\right)^{b}$ & $\begin{array}{l}\text { Number of firms in country } i \text { in the } 9^{\text {th }} \text { decile of the world distribution of firm sales } \\
\text { in a given sector } h \text {. } \\
\text { Source: Worldscope Database }\end{array}$ \\
\hline Num. of large firms $\left(10^{\text {th }} \text { decile }\right)^{b}$ & $\begin{array}{l}\text { Number of firms in country } i \text { in the } 10^{\text {th }} \text { decile of the world distribution of firm } \\
\text { sales in a given sector } h \text {. } \\
\text { Source: Worldscope Database }\end{array}$ \\
\hline Num. of large firms $\left(4^{\text {th }} \text { quintile }\right)^{b}$ & $\begin{array}{l}\text { Number of firms in country } i \text { in the } 4^{\text {th }} \text { quintile of the world distribution of firm } \\
\text { sales in a given sector } h \text {. } \\
\text { Source: Worldscope Database }\end{array}$ \\
\hline Num. of large firms $\left(5^{\text {th }} \text { quintile }\right)^{b}$ & $\begin{array}{l}\text { Number of firms in country } i \text { in the } 5^{\text {th }} \text { quintile of the world distribution of firm } \\
\text { sales in a given sector } h \text {. } \\
\text { Source: Worldscope Database }\end{array}$ \\
\hline Sales dispersion ${ }^{a}$ & $\begin{array}{l}\text { Standard deviation of the world distribution of the size of firms, measured by total } \\
\text { sales, in a given sector } h \text {. } \\
\text { Source: Worldscope Database }\end{array}$ \\
\hline \multicolumn{2}{|r|}{ Sector-level variables for the country of origin } \\
\hline Capital intensity $^{a}$ & $\begin{array}{l}\text { Ratio between capital and number of employees in sector } h \text { in country } i \text {. } \\
\text { Source: UNIDO (Indstat } 4,2008 \text { version) }\end{array}$ \\
\hline Patents $^{b}$ & $\begin{array}{l}\text { Number of patents produced in a country } i \text { and in a given sector } h \text { and granted by } \\
\text { the US Patent Office. } \\
\text { Source: NBER }\end{array}$ \\
\hline \multicolumn{2}{|r|}{ Bilateral country-level variables } \\
\hline Distance $^{a}$ & $\begin{array}{l}\text { Average distance between countries } i \text { and } j \text { calculated through the great circle } \\
\text { formula that uses latitudes and longitudes of the most important cities (in terms of } \\
\text { population). } \\
\text { Source: CEPII } \\
\text { http://www.cepii.fr/anglaisgraph/bdd/distances.htm }\end{array}$ \\
\hline Islands & $\begin{array}{l}\text { Number of countries that are islands in the pair of countries } i \text { and } j \text {. } \\
\text { Source: CEPII } \\
\text { http://www.cepii.fr/anglaisgraph/bdd/distances.htm }\end{array}$ \\
\hline
\end{tabular}

case we do not know what are the foreign markets (possibly) involved, while in the latter case we have no information about foreign controls: as a consequence, we exclude domestic M\&A from our sample. 
Table 1 (continued)

\begin{tabular}{|l|l|}
\hline Common language & $\begin{array}{l}\text { Dummy variable equal to 1 if country } i \text { and } j \text { share the same language. } \\
\text { Source: CEPII } \\
\text { http://www.cepii.fr/anglaisgraph/bdd/distances.htm }\end{array}$ \\
\hline Common religion & $\begin{array}{l}\text { Dummy variable equal to 1 if country } i \text { and } j \text { share the same religion. } \\
\text { Source: CEPII } \\
\text { http://www.cepii.fr/anglaisgraph/bdd/distances.htm }\end{array}$ \\
\hline Bariffs ${ }^{b}$ & $\begin{array}{l}\text { Tariffs applied from country } j \text { to country } i \text { in sector } h . \\
\text { Source: TRAINS }\end{array}$ \\
\hline Common partners in trade $b$ & $\begin{array}{l}\text { Number of partners in trade common to country } i \text { and } j \text { in sector } h . \\
\text { Source: UN Comtrade }\end{array}$ \\
\hline Common partners in FDI ${ }^{b}$ & $\begin{array}{l}\text { Number of partners in FDI common to country } i \text { and } j \text { in sector } h . \\
\text { Source: SDC Platinum }\end{array}$ \\
\hline
\end{tabular}

${ }^{\mathrm{a}}$ This variable is included in the estimations as $\ln$ (variable).

${ }^{\mathrm{b}}$ This variable is included in the estimations as $\ln (1+$ variable $)$.

Using these information we build an indicator variable at the country and sector levels. This indicator is constructed in such a way that higher values correspond to greater involvement of sector in international activities. This variable $(y)$ distinguishes between sectors that are not internationalized at all (with a value of zero), sectors that internationalize only through trade (with a value of one) and those that have both trade and FDI (with a value of two).

\subsection{Key independent variables}

Our two key explanatory variables are measures of productivity and firm size. The average industry TFP is calculated under the assumption of constant returns to scale Cobb-Douglas production function as:

$\operatorname{TFP}_{i}^{h}=\frac{Y_{i}^{h}}{\left(K_{i}^{h}\right)^{\alpha}\left(L_{i}^{h}\right)^{1-\alpha}}$

where $Y_{i}^{h}$ is value added in sector $h$ of country $i ; K_{i}{ }^{h}$ and $L_{i}^{h}$ are the stock of capital and the number of employees in sector $h$ of country $i$, respectively; and $\alpha$, the capital share, is assumed to be $1 / 3$.

Total factor productivity at the national sector level is calculated from data on investment and labour from UNIDO (Indstat4, 2008 version), where each sector's capital stock is estimated by the 
inventory method (Bernanke and Gurkaynak 2002; Isaksson 2009). In particular: (i) for each country, we calculate the sector's share of investment using flow information for the first five years of data available; (ii) we use investment shares to allocate each country's total capital, sourced from the UNIDO's World Productivity Database, across sectors; (iii) we use the estimates of the country and sector specific initial stock of capital obtained as described above as the starting point to apply the inventory method, i.e., adding each year's value of real term investment and applying a sector specific rate of depreciation to account for obsolescence.

The use of TFP as a measure of productivity implies that Germany is excluded from the analysis since data on aggregate capital are not available from the UNIDO's World Productivity Database. However, Germany is included in the sample used for the robustness check based on an alternative measure of productivity, namely the ratio between value added and number of employees in a given sector. Data on labour productivity are drawn from UNIDO (Indstat4, 2008 version).

To measure the distribution of firms by size in a sector, we first calculate the deciles of the world distribution of firms by total sales in each sector and then we count the number of firms that each country has in the $10^{\text {th }}$ decile of the world/sector distribution. ${ }^{14}$ This indicator proxies for the incidence in each country and sector of those firms that are large enough to overcome the higher fixed costs of expanding abroad through FDI rather than exports (Helpman et al. 2004).

As additional measures of large firms in a sector, we use alternatively: $(i)$ the number of firms in the $9^{\text {th }}$ and $10^{\text {th }}$ decile of the world distribution of firms by size, (ii) the number of firms in the $7^{\text {th }}$ decile and higher of the world distribution of firms by size and (iii) the dispersion of the distribution of sales within sectors - that allows to compare our results with those obtained by Helpman et al. (2004).

Data on firm's sales are drawn from the Worldscope database, that includes financial statements of about 29,000 companies listed in developed and emerging markets, representing approximately $95 \%$ of the global market capitalization. Since we focus on large firms, excluding non-listed companies is unlikely to introduce a relevant bias in our measure of each sector's ability to internationalize. Data are classified according to the SIC classification at 4-digits level.

\footnotetext{
${ }^{14}$ Considering the world rather than the national distribution(s) we avoid the risk of a country-specific definition of "large firms". On the other hand, the total number of firms in each sector may be influenced by technological peculiarities, such as the existence of economies of scale. To account for this issue, it is possible either to use the share rather than the absolute number of large firms or, as we do in this paper, account for all sector-specific features through the use of sector dummies.
} 


\subsection{Control variables}

To limit the potential for omitted-variable bias, we add to the main variables of interest three sets of controls, that are based on the vast literature focusing on trade and on M\&A. First, we control for some relevant sector characteristics in the country of origin. Second, we control for a set of characteristics of the bilateral relationship between each couple of countries. Finally, we include some sector characteristics that are specific to each pair of countries.

\subsubsection{Sector-level variables for the country of origin}

Helpman et al. (2004) show that capital intensity is a useful predictor of a larger incidence of exports relative to FDI while the opposite is true as far as technological intensity is concerned. Accordingly, we use the ratio between capital and number of employees for each country and sector from UNIDO to construct a measure of capital intensity, and the number of utility patents granted by the US Patent Office, provided by the national bureau of economic research (NBER), also at the country and sector level, as a measure of technological intensity. ${ }^{15}$

\subsubsection{Bilateral country-level variables}

The empirical literature has identified a large set of variables that influence foreign market entry modes, though the magnitudes and even the signs of the impact on either trade or FDI are not always consistent (see, for example, Blonigen 2005; Disdier and Head 2008; Helpman et al. 2008; Herger et al. 2008; Oldenski 2010; Slangen and Beugelsdijk 2010; Wang et al. 2010; Slangen et al. 2011). Distance directly increases transaction costs because of the transportation costs of shipping products, the cost of acquiring information about other economies, and the cost of finding a partner and contracting at a distance. Similarly, the number of islands in each country pair, common language and common religion are expected to affect bilateral relationships, both through trade and investment.

Our data on bilateral characteristics are drawn from the dataset provided by the centre d'etudes prospectives et d'informations internationales (CEPII). ${ }^{16}$

\footnotetext{
${ }^{15}$ Since the original data on patents are classified according to the US Patent Classification, we combined them with other information adopting the correspondence scheme between the US Patent Classification and the International Patent Classification and between the latter and the ISIC3 provided by Johnson (2002).

${ }^{16}$ The CEPII follows the great circle formula and uses latitudes and longitudes of the most important cities (in terms of population) to calculate the average of distances between city pairs. Data on distances are available at: http://www.cepii.fr/anglaisgraph/bdd/distances.htm. We also adopted distances between capitals as an alternative measure and the results remain unchanged.
} 


\subsubsection{Bilateral country-and sector-level variables}

We consider two bilateral sector-level variables. First, bilateral trade tariffs, that we expect to favor FDI, according to the well-known "tariff jumping" effect pointed out in the literature (Brainard 1997; Carr et al. 2001; Markusen and Maskus 2002; Yeaple 2003; Helpman et al. 2004). To make data comparable to other data used in the analysis, we aggregate HS 6-digits level data on tariffs from TRAINS to the 4-digits ISIC classification through simple averages. Second, building on the results of Chaney (2011) - who show that the existing contacts of a firm can be used to find new ones - we include in our specification two "network indexes" calculated as the number of common partners in trade and in M\&A of each couple of countries (Francois 2010). We expect that a higher number of common partners in exports (or in M\&A) between two countries increases the probability of exporting (or doing M\&A) between those same countries. ${ }^{17}$ Data on the number of common partners is built from our information on trade and FDI.

\subsection{Sample summary statistics}

Matching our different sources, we construct an original database that associates bilateral trade and FDI flows at the sector level in a common classification, for a sample of developed as well as developing countries. Industries including finance and utilities are excluded, along with wholesale and retail trade, because of the non-tradable nature of these activities. We also exclude agriculture and primary sectors (i.e., mining and oil and gas extraction) due to the lack of data on productivity. As a result, we focus on manufacturing sectors (i.e., sectors with an ISIC code between 1511 and 3720).

Since our measures of M\&A and sales are available in the SIC classification, we mapped SIC codes into ISIC codes, both at 4-digits level, using the concordances produced by Statistics Canada, as in Brakman et al. (2005). ${ }^{18}$ To take into account that at the 4-digits level of disaggregation we have a large number of empty cells, both in exports and in M\&A, we aggregate data available at 3 digits of ISIC classification. Matching the different sources yields a dataset including 24 origin countries and 91 destination countries, covering 57 manufacturing industries at the 3 digits ISIC level from 1994 to 2004.

\footnotetext{
${ }^{17}$ There is a growing literature focusing on the extensive margin of trade, i.e. trading relationships regarding new products or countries that never traded with each other in the past: see, for instance, Felbermayr and Kohler (2006).

${ }^{18}$ Concordance tables are available from: http://www.macalester.edu/research/economics.
} 
Table 2 presents the descriptive statistics for the variables used in the estimations, showing substantial variation in all our key variables. ${ }^{19}$ TFP shows a high variability around the average, and sectors presenting (on average) the highest TFP are: Refined petroleum products, Tobacco products, Motor vehicles and Automobiles. Labour productivity presents an even larger variability; sectors featuring the highest labor productivity are: Tobacco products, Refined petroleum products and Manmade filament tow or staple fibers.

The average number of firms in the $10^{\text {th }}$ decile of the world distribution of firms by total sales is 2 and shows a high within sample variability, with values ranging from 0 to 52 . The number of patents, reflecting the level of technological development, shows an average value of 17 and a high variability since it ranges between 0 and 1,465 .

\footnotetext{
${ }^{19}$ Descriptive statistics are computed on the largest sample, i.e. the one including Germany in the group of domestic country.
} 
Table 2 - Summary statistics (whole sample)

\begin{tabular}{|l|c|c|c|c|c|c|c|c|}
\hline Variable & Mean & Median & St. dev. & Min & $\mathbf{2 5}^{\text {th }}$ & $\mathbf{7 5}^{\text {th }}$ & Max & Obs. \\
\hline \hline TFP & 206.043 & 179.537 & 185.047 & 9.590 & 118.977 & 240.535 & $2,448.199$ & 67,975 \\
Labour productivity & 606.414 & 514.074 & 689.905 & 11.125 & 282.181 & 704.687 & $13,135.190$ & 72,904 \\
Num. of large firms $\left(9^{\text {th }}\right.$ decile) & 2.230 & 0.364 & 5.662 & 0 & 0 & 1.600 & 52.818 & 72,904 \\
Num. of large firms $\left(10^{\text {th }}\right.$ decile) & 2.353 & 0 & 5.999 & 0 & 0 & 1.714 & 51.727 & 72,904 \\
Num. of large firms $\left(4^{\text {th }}\right.$ quintile) & 4.193 & 1 & 9.733 & 0 & 0.200 & 3.182 & 83.143 & 72,904 \\
Num. of large firms $\left(5^{\text {th }}\right.$ quintile) & 4.583 & 0.909 & 11.498 & 0 & 0 & 3.091 & 104.546 & 72,904 \\
Sales dispersion & 1.499 & 1.223 & 1.084 & 0.030 & 0.791 & 1.951 & 7.840 & 72,825 \\
Capital intensity & 1.681 & 1.664 & 0.178 & 1.309 & 1.565 & 1.774 & 2.468 & 67,975 \\
Patents & 17.236 & 0.008 & 86.534 & 0 & 0 & 2.682 & $1,465.436$ & 72,904 \\
Distance & 8,322 & 8,224 & 4,237 & 215 & 5,519 & 10,470 & 19,772 & 72,904 \\
Islands & 0 & 0 & 1 & 0 & 0 & 1 & 2 & 72,904 \\
Common language & 0 & 0 & 0 & 0 & 0 & 0 & 1 & 72,904 \\
Common religion & 0 & 0 & 0 & 0 & 0 & 0 & 1 & 72,904 \\
Tariffs & 0.117 & 0.093 & 0.108 & 0 & 0.034 & 0.172 & 0.582 & 72,904 \\
Common partners in trade & 57.931 & 57 & 36.866 & 0 & 24 & 92 & 117 & 72,904 \\
Common partners in FDI & 0.399 & 0 & 1.440 & 0 & 0 & 0 & 30 & 72,904 \\
\hline \hline
\end{tabular}

Variables description and sources are provided in Table 1. Summary statistics are computed after excluding influential outliers. $25^{\text {th }}$ and $75^{\text {th }}$ refer to the percentiles of the world distribution. All descriptive statistics are computed on variables in levels.

Among bilateral characteristics, tariffs show a high variability, with values ranging between 0 and $58 \%$ and an average level of $12 \%$. The average number of common partners in trade is 58 , with values ranging between 0 and 117, whereas the average number of common partners in FDI is much lower and the range narrower (between 0 and 30). This difference highlights that the two "networks" are quite different and the former is much larger than the latter.

Table 3 reports the summary statistics (means and standard deviations) for all variables in our data set, distinguishing among "domestic", "export" and "export and FDI" sectors. The first category, grouping 5,917 observations, includes country pairs-sectors not involved in an international relationship at all; the second, by far the most numerous (62,758 observations), includes country pairssectors that are involved in exports only; the third category, featuring 4,229 observations, includes country pairs-sectors that are involved in both exports and FDI. The distribution of the key explanatory variables in the three samples sends a clear message: the higher the internationalization involvement of sectors, the higher the level of productivity and the presence of large firms, independently of the measure adopted. This suggests, as expected, that sectors that are involved both in trade and in investment are the most productive and show the highest incidence of large firms. Sectors that are only active in exports represent $86 \%$ of our sample, while domestic and exporter and investor sectors represent, respectively, $8 \%$ and $6 \%$ of the total. 
Table 3 - Summary statistics by international involvement

\begin{tabular}{|c|c|c|c|c|c|c|}
\hline \multirow[b]{2}{*}{ Variable } & \multicolumn{2}{|c|}{ Domestic } & \multicolumn{2}{|c|}{ Export } & \multicolumn{2}{|c|}{ Export and FDI } \\
\hline & Mean & St. dev. & Mean & St. dev. & Mean & St.dev. \\
\hline TFP & 159.973 & 204.127 & 208.325 & 184.885 & 242.277 & 138.110 \\
\hline Labour productivity & 375.653 & 662.184 & 611.656 & 684.608 & 851.495 & 708.312 \\
\hline Num. of large firms $\left(9^{\text {th }}\right.$ decile $)$ & 0.399 & 1.756 & 2.057 & 5.221 & 7.362 & 10.603 \\
\hline Num. of large firms $\left(10^{\text {th }}\right.$ decile $)$ & 0.371 & 1.851 & 2.153 & 5.491 & 8.089 & 11.369 \\
\hline Num. of large firms ( $4^{\text {th }}$ quintile) & 1.217 & 3.229 & 3.903 & 9.015 & 12.663 & 18.083 \\
\hline Num. of large firms ( $5^{\text {th }}$ quintile $)$ & 0.770 & 3.529 & 4.210 & 10.550 & 15.450 & 21.670 \\
\hline Sales dispersion & 1.061 & 0.667 & 1.476 & 1.047 & 2.452 & 1.469 \\
\hline Capital intensity & 1.624 & 0.197 & 1.688 & 0.177 & 1.662 & 0.146 \\
\hline Patents & 2.029 & 19.977 & 15.195 & 78.790 & 68.804 & 182.669 \\
\hline Distance & 10,069 & 4,383 & 8,236 & 4,185 & 7,166 & 4,116 \\
\hline Islands & 0 & 1 & 0 & 1 & 0 & 1 \\
\hline Common language & 0 & 0 & 0 & 0 & 0 & 0 \\
\hline Common religion & 0 & 0 & 0 & 0 & 0 & 0 \\
\hline Tariffs & 0.105 & 0.112 & 0.121 & 0.107 & 0.083 & 0.097 \\
\hline Common partners in trade & 51.811 & 35.840 & 55.774 & 36.149 & 98.495 & 21.785 \\
\hline Common partners in FDI & 0.082 & 0.354 & 0.254 & 0.841 & 2.992 & 4.229 \\
\hline Observations & \multicolumn{2}{|c|}{5,917} & \multicolumn{2}{|c|}{62,758} & \multicolumn{2}{|c|}{4,229} \\
\hline
\end{tabular}

Variables description and sources are provided in Table 1. Summary statistics are computed, after excluding influential outliers, on three groups of sectors depending on internationalization involvement: "domestic", "export" and "export and FDI". All descriptive statistics are computed on variables in levels.

Table 4 reports simple correlations among the variables used in the empirical model. TFP and labour productivity levels are positively correlated with the dependent variable: higher levels of productivity in a given sector determine higher internationalization and higher probability of both trade and investment. Further, the correlation between the ordered dependent variable distinguishing internationalization and the number of large firms is positive, suggesting that having firm distribution by size shifted towards large firms favours both trade and FDI.

Even though summary statistics and bilateral correlations are suggestive, they do not control for potentially confounding factors. For this reason, in what follows we perform a more refined econometric analysis. 
Table 4 - Correlation matrix

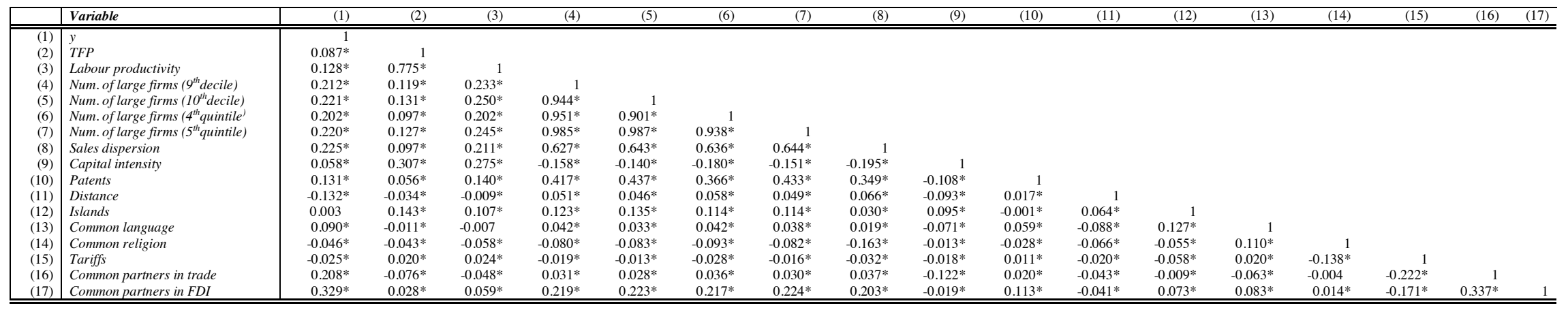

Variable description and sources are provided in Table 1 . Correlations are computed after excluding influential outliers. $*$ indicates significance at the $1 \%$ level. Correlations are computed on variables in levels. 


\section{Results}

\subsection{Estimations on the whole sample}

The first step of our empirical analysis consists in estimating the ordered probit model described in equation (5) on the whole sample that includes the 67,975 cases. This approach allows us to analyse the impact of our variables of interest, along with other controls, on the probability and the degree of different internationalization involvement. ${ }^{20}$

Results in column (1) of Table 5 show that the average level of TFP has a positive and statistically significant impact at the $99 \%$ level on foreign expansion. This result is qualitatively consistent with the theoretical hypothesis that more productive sectors internationalize. Since the sign of the coefficient can only tell us about how an independent variable affects the probability of the end categories (Greene 2008 ; Wooldridge 2010), to get a sense of the magnitude of this impact, columns (2-4) of Table 5 report the changes in the predicted probability of each category for a variation of sector TFP from the level at the $25^{\text {th }}$ percentile of the world distribution to that at the $75^{\text {th }}$ percentile. A growth of TFP of this size would determine a decrease of $8.9 \%$ of the predicted probability for a sector to remain at home. Conversely, this decrease is offset by an increase of $2.1 \%$ in the predicted probability of foreign expansion through export only and by an increase of $6.8 \%$ if we consider also foreign investment.

Similar results are obtained for our second key explanatory variable: a shift of the distribution of firms by size to the right increases the probability for a sector to internationalize. Even controlling for other covariates as well as industry and country dummies, the positive impact of the number of large firms in a sector is confirmed. The positive impact of this variable, statistically significant at the $99 \%$ level, is consistent with our second hypothesis: when the distribution of firms in a given sector-country is shifted towards large firms, it is more likely that domestic sectors begin to explore foreign markets, via exports and/or foreign investment. Looking at the economic impact, an increase in the number of large firms from the $25^{\text {th }}$ to the $75^{\text {th }}$ percentile reduces the probability mass of being "domestic" sector by $3.9 \%$ and favours internationalization through export only (by increasing the probability by $1.6 \%$ ) and through both exports and investment (by increasing the probability by $2.3 \%$ ). This impact is much lower than that of productivity.

\footnotetext{
${ }^{20}$ All estimations reported include three sets of dummies controlling for the domestic country, the foreign country and the sector-specific fixed effects, as described in Section 3.
} 
Table 5 - Ordered probit on the whole sample

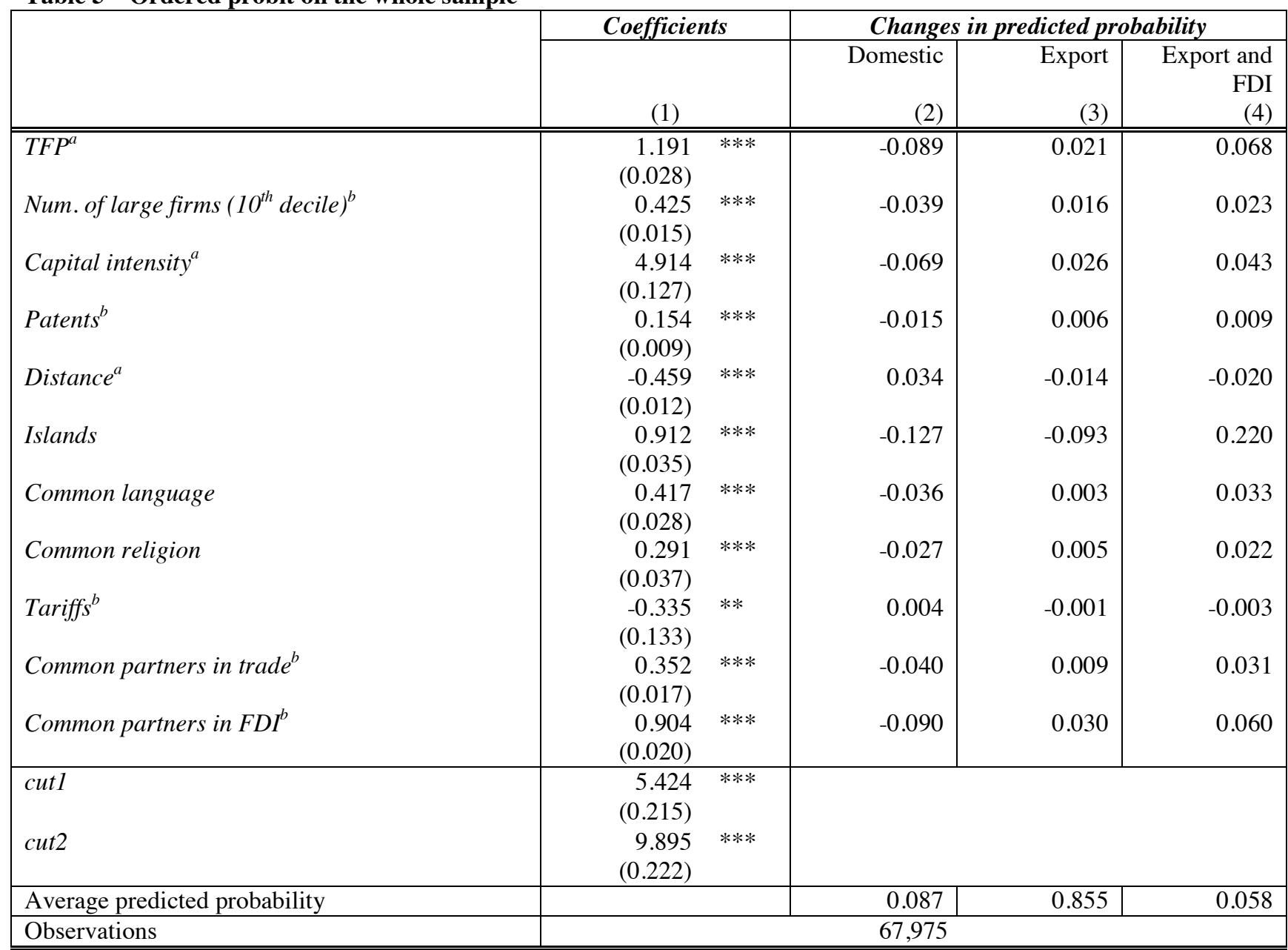

Variables description and sources are provided in Table 1. Column (1) reports coefficients of estimations. Columns (2)-(4) report changes in predicted probability for continuous variables varying from $25^{\text {th }}$ to $75^{\text {th }}$ of the world distribution, for discrete variables or dummies varying from the minimum to the maximum value and marginal effects for "Common partners in FDI". cutl and cut2 indicate thresholds between one category and the next. Standard errors robust to heterosckedasticity are reported in parentheses. Standard errors for cut points are calculated with the delta method. ***,** and $*$ indicate statistical significance at the $1 \%, 5 \%$ and $10 \%$ level, respectively.

${ }^{a}$ This variable is included as $\ln ($ variable).

${ }^{\mathrm{b}}$ This variable is included as $\ln (1+$ variable $)$.

Overall, these results provide support to the hypotheses stated in Section 2 that sectors characterized by a high level of productivity and by a higher incidence of large firms are more likely to be able to afford the higher fixed costs required to serve foreign consumers. These results are consistent with the theoretical model of Helpman et al. (2004) suggesting that larger and more productive firms should be more likely to internationalize through foreign investment. Indeed, the changes in the probability associated with an increase in productivity and the number of large firms should be compared with the average predicted probability (i.e., the average proportion of country/sector 
observations for each internationalization mode), that is $86 \%$ for sectors doing exports only and $6 \%$ for sectors doing both exports and FDI. An increase of $2.3 \%$ on an average of $6 \%$ (as the one associated with an improvement in firm size) is indeed economically less relevant than an increase of $1.6 \%$ on a share of $86 \%$. Accordingly, the relative impact on the share of observations using both internationalization strategies (i.e., exports and FDI) is much larger (38\%) than that of using only exports $(2 \%)$.

Concerning other control variables, the level of capital intensity and the innovation activity also favour internationalization of sectors. In particular, an increase in capital and technological intensity makes sectors to leave the "domestic" category in favour of the "export" and, even more, "export and FDI" categories. ${ }^{21}$ Regarding country-level bilateral characteristics, a first group of control variables (i.e., distance, and tariffs) presents a negative and statistically significant impact on the probability of foreign expansion. These results provide evidence that such factors induce firms to remain at home, instead of internationalize through export and/or FDI. It may be surprising that distance has a larger negative impact on "export and FDI" than on "export" alone but, even if we control for bilateral features concerning language or religion, the geographical distance is likely to be positively related to other variables increasing the cost of investing abroad. In the same vein, the restraining impact of tariffs is larger when both internationalization modalities are taken into account. This may suggest the absence of "tariff-jumping" FDIs, although it should be recalled that our "2" category lumps together both exports and FDIs.

The opposite is true for a second group of bilateral characteristics (i.e. islands, common language and common religion), showing a positive impact on internationalization choices and especially on the export and FDI mode. Finally, the coefficients associated with the number of common partners in trade or FDI confirms the relevance of the network effects. Apparently, firms in sectors with a higher number of foreign contacts are more likely to enter an additional market, and sectors benefit from the contacts of their contacts. In other words, if a firm $k$ has a contact in country $j$ ' which itself has a contact in country $j$, then firm $k$ is more likely to enter country $j$. However, the FDI network has an impact almost three times larger than the trade one.

The remaining threshold parameters are estimated together with the coefficients of our independent variables. The value of these parameters define the boundaries between different

\footnotetext{
${ }^{21}$ These results are consistent with those of Helpman et al. (2004) as far as capital intensity is concerned, not in the case of innovation activity. It should be noted, though, that we differ from them in terms of the variable used to proxy for innovation: the number of patents rather than R\&D expenses.
} 
categories of internationalization. In our estimates, both threshold values are statistically significant and their coefficients are different from 1, implying that the ordinal categories are not equally spaced (Basile et al. 2003). In unreported analyses, available upon request, we also verified that cut-off points are also statistically different from each other, meaning that observed internationalization categories do not overlap.

\subsection{Does the level of country development matter?}

Up to now, we have estimated the ordered probit on the whole sample of observations, and we have found that sectors characterized by a high level of productivity and by a higher incidence of large firms are more likely to be able to afford the higher fixed costs required to serve foreign consumers. However, since our sample includes several origin and destination countries with different levels of development, it is of interest to analyze the behavior of sectors in the internationalization process in different groups of countries. As a matter of fact, non-traditional source countries of FDI play an increasingly important role, and this raises the question of whether the determinants of FDI differ systematically between developed and developing countries (Sosa et al. 2012).

For this reason, in Tables 6-8 we present the findings obtained considering different samples of countries. In particular, we concentrate on developed countries as origin and we first estimate the internationalization strategies for the sample of developed countries towards all destination countries and then we split the destination sample into developed and developing countries. ${ }^{22}$

As it can be inferred from Table 6, restricting the sample of origin countries to developed countries does not change the overall picture in terms of our hypotheses.

\footnotetext{
${ }^{22}$ In addition, firms in developing countries face difficulties in expanding in their countries as a result of a less developed institutional environment. However, multinational firms in developing countries may be successful in other countries, despite these disadvantage in their country of origin. In other estimates, not reported but available on request, we have found that sectors from developing countries are more likely to internationalize the higher the level of TFP. On the other hand, the distribution of firms by size is not relevant.
} 
Table 6 - Developed countries as origin vs. all other countries

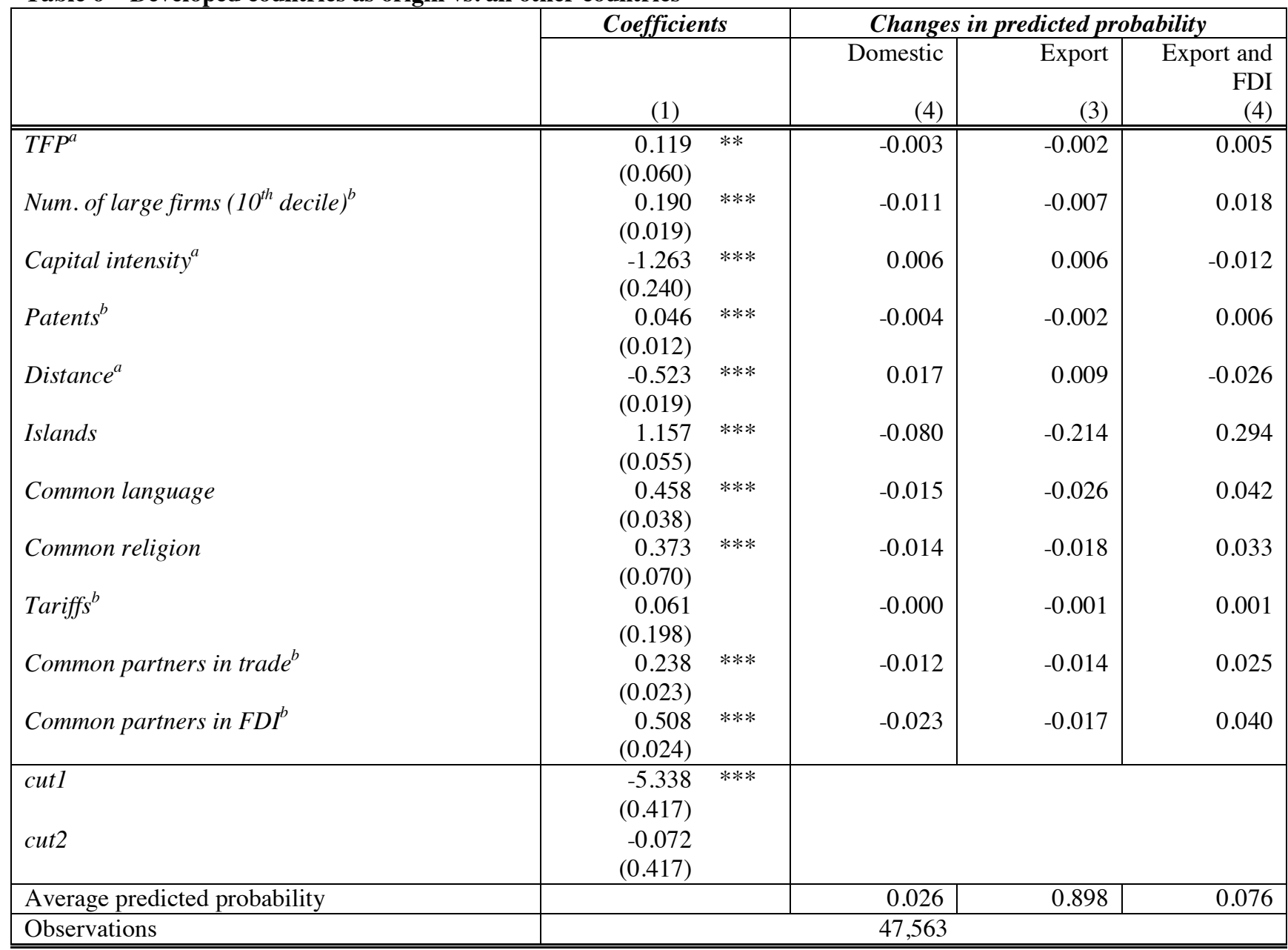

Variables description and sources are provided in Table 1. Column (1) reports coefficient of estimations. Columns (2)-(4) report changes in predicted probability for continuous variables varying from $25^{\text {th }}$ to $75^{\text {th }}$ of the world distribution, for discrete variables or dummies varying from the minimum to the maximum value and marginal effects for "Common partners in FDI". cutl and cut2 indicate thresholds between one category and the next. Standard errors robust to heterosckedasticity are reported in parentheses. Standard errors for cut points are calculated with the delta method. ***,** and $*$ indicate statistical significance at the $1 \%, 5 \%$ and $10 \%$ level, respectively.

${ }^{a}$ This variable is included as $\ln ($ variable).

${ }^{\mathrm{b}}$ This variable is included as $\ln (1+$ variable $)$.

The impact of productivity level and the distribution of firms by sales is lower for "export" and "export and FDI" modes of internationalization than that of the whole sample. In particular, looking at the economic impact, a growth of TFP from the $25^{\text {th }}$ to the $75^{\text {th }}$ percentile would determine a decrease of $0.3 \%$ of the predicted probability for a sector to remain at home. Conversely, this decrease is offset by an increase of $0.2 \%$ in the predicted probability of foreign expansion through export only and by an increase of $0.5 \%$ if we consider also foreign investment. On the other hand, an increase in the number of large firms from the $25^{\text {th }}$ to the $75^{\text {th }}$ percentile reduces the probability mass of being "domestic" 
sector by $1.1 \%$ and favours internationalization through export only (by increasing the probability by $0.7 \%$ ) and through both exports and investment (by increasing the probability by $2 \%$ ). This impact is much higher than that of productivity. Restricting the sample to developed countries, our hypotheses are therefore confirmed, even though the impact of our key explanatory variables, in absolute and relative terms, is lower than that on the whole sample. The sign and the significance of the other coefficients remain by and large unchanged, with only few exceptions. ${ }^{23}$

Considering the same sample of developed countries as origins, and distinguishing between destination countries, we found some interesting results. As reported in Table 7, the internationalization process of developed countries towards other developed countries is not affected by productivity. The coefficient of TFP is indeed negative, but it is not statistically significant. On the other hand, the distribution of firms by size is still a determinant of the choice of serving foreign markets.

Nunnenkamp (2002, p.1) argues that "the boom of FDI flows to developing countries since the early 1990s indicates that multinational enterprises have increasingly considered these host countries to be profitable investment locations." Moreover, "one of the most important traditional FDI determinants, the size of national markets, has decreased in importance. At the same time, cost differences between locations, the quality of infrastructure, the ease of doing business and the availability of skills have become more important" (UNCTAD 1996, p. 97). In addition, international trade flows toward developing countries have recently grown, even though this expansion have been much lesser than that of international capital flow (Taylor and Sarno 1997). For these reasons, we focus on sectors in developed countries internationalizing towards other developing counterparts and results are reported in Table 8 . This table shows that they are both more productive and have a higher presence of large firms. Also in this case, the coefficients of the other control variables remain by and large unchanged. The only relevant exception is the coefficient of tariffs, that becomes statistically insignificant. A possible explanation is that tariffs imposed by developing countries are often used not only to protect imports from other countries, but also to finance public balances. Moreover, imports demand curve for products of high quality produced by advanced economies is already inelastic despite

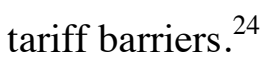

\footnotetext{
${ }^{23}$ It should be recalled that to compare the point estimates across samples and groups within samples, it is necessary to assume that the unobserved heterogeneity is the same across the compared samples or groups (Mood 2010).

${ }^{24}$ In unreported regressions, available on request, we obtain similar results for the group of developing countries as destination of international expansion from all other countries (i.e. both developed and developing).
} 
Table 7 - Developed countries as origin vs. other developed countries

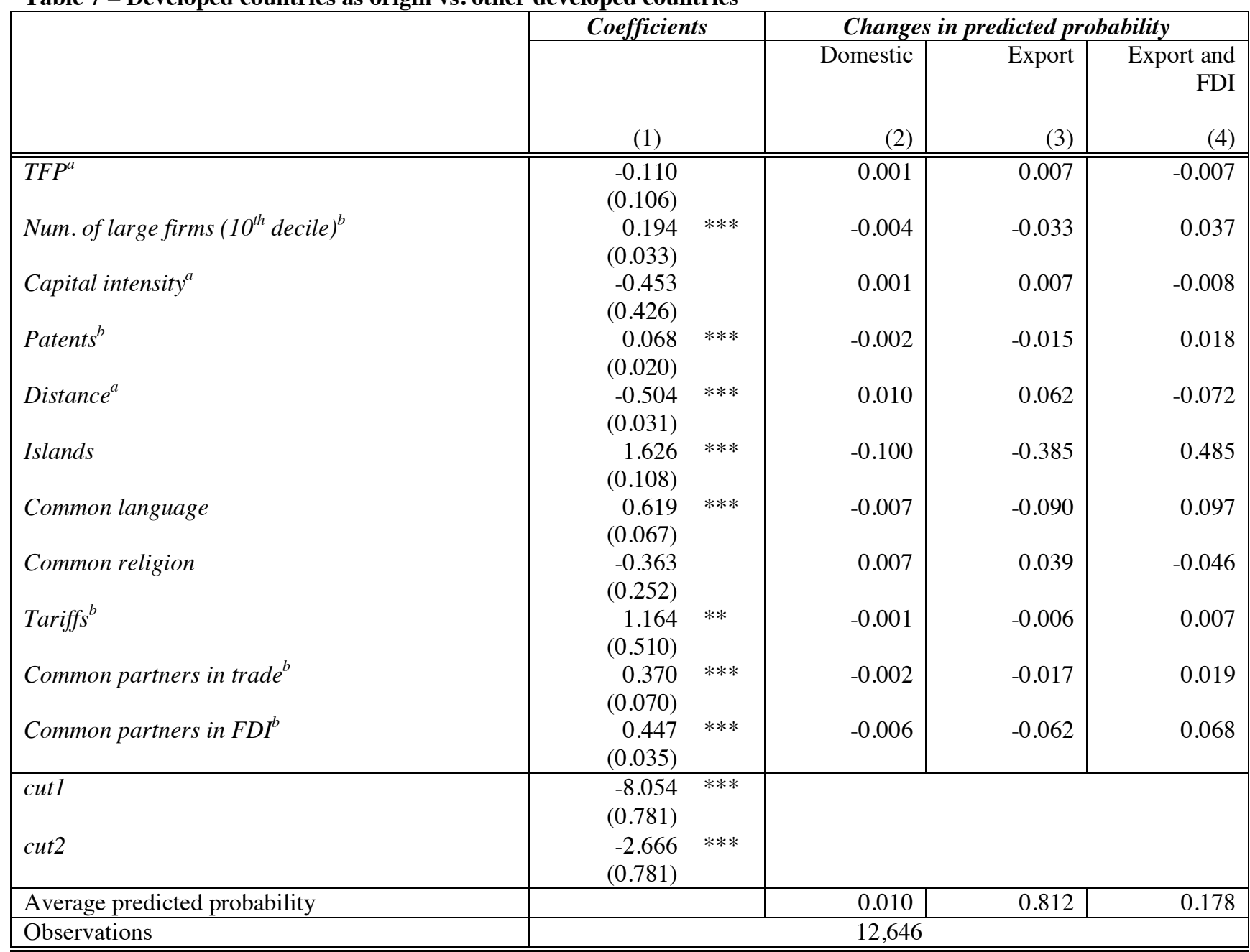

Variables description and sources are provided in Table 1. Column (1) reports coefficient of estimations. Columns (2)-(4) report changes in predicted probability for continuous variables varying from $25^{\text {th }}$ to $75^{\text {th }}$ of the world distribution, for discrete variables or dummies varying from the minimum to the maximum value and marginal effects for "Common partners in FDI". cut1 and cut 2 indicate thresholds between one category and the next. Standard errors robust to heterosckedasticity are reported in parentheses. Standard errors for cut points are calculated with the delta method. ***,** and $*$ indicate statistical significance at the $1 \%, 5 \%$ and $10 \%$ level, respectively.

${ }^{a}$ This variable is included as $\ln$ (variable).

${ }^{\mathrm{b}}$ This variable is included as $\ln (1+$ variable $)$. 
Table 8 - Developed countries as origins vs. developing countries

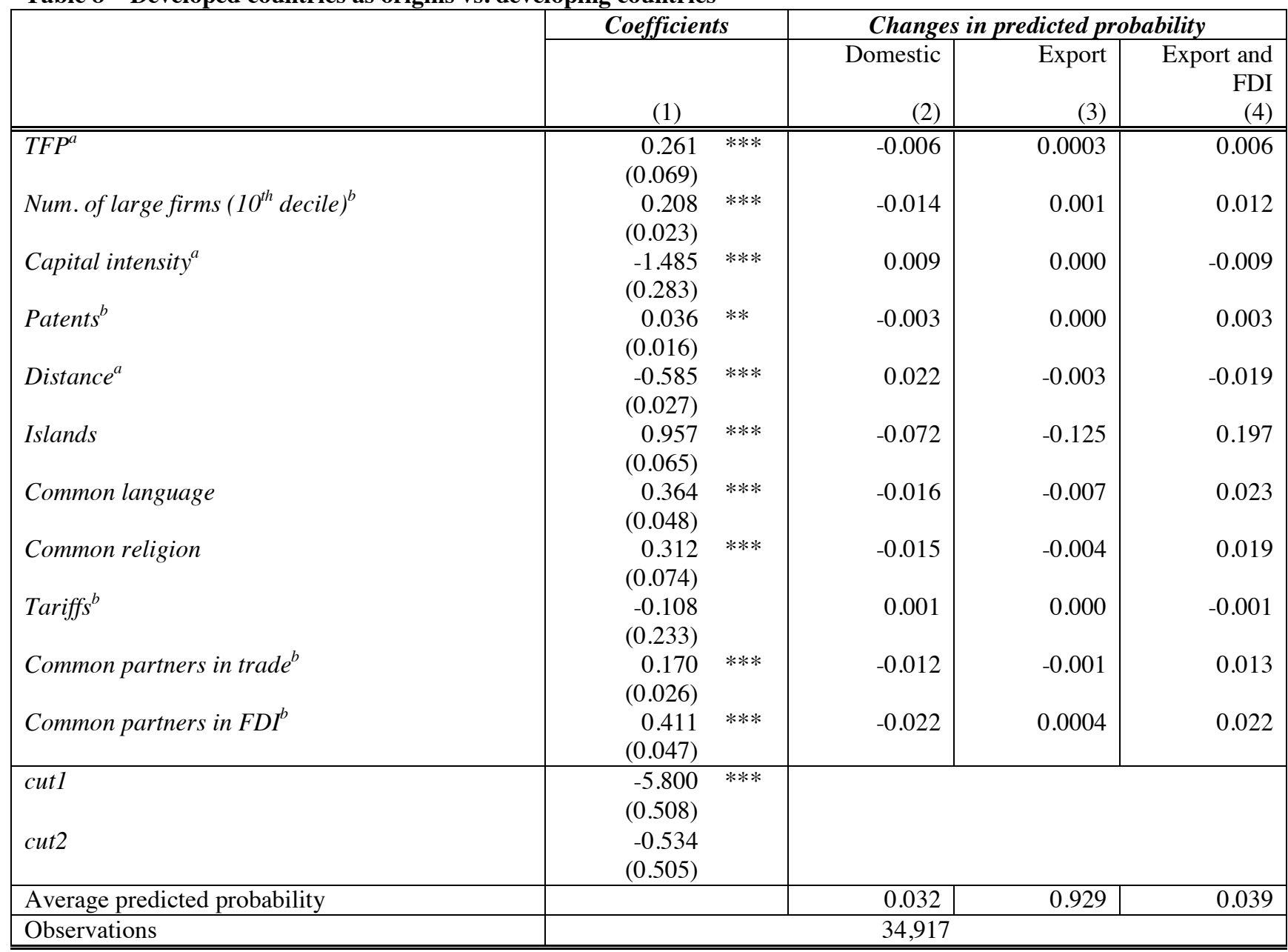

Variables description and sources are provided in Table 1. Column (1) reports coefficient of estimations. Columns (2)-(4) report changes in predicted probability for continuous variables varying from $25^{\text {th }}$ to $75^{\text {th }}$ of the world distribution, for discrete variables or dummies varying from the minimum to the maximum value and marginal effects for "Common partners in FDI". cutl and cut2 indicate thresholds between one category and the next. Standard errors robust to heterosckedasticity are reported in parentheses. Standard errors for cut points are calculated with the delta method. ***,** and $*$ indicate statistical significance at the $1 \%, 5 \%$ and $10 \%$ level, respectively.

${ }^{a}$ This variable is included as $\ln ($ variable).

${ }^{\mathrm{b}}$ This variable is included as $\ln (1+$ variable $)$.

\subsection{Robustness checks: different measures of the number of large firms and labour productivity}

In our empirical specification we have employed the number of firms in the $10^{\text {th }}$ decile as an indicator of the distribution of firms by size. However, this could be considered as an ad-hoc choice. For this reason, Table 9 reports several robustness checks aimed at verifying that our results do not depend on the specific threshold adopted. In particular, we use three different thresholds to define large firms in a sector: the number of firms in the $9^{\text {th }}$ and $10^{\text {th }}$ decile of the distribution, those in the $7^{\text {th }}$ decile and 
higher, and a measure of the dispersion of sales in a sector. The last measure, that is constructed as described in Section 4.2, is similar to that adopted by Helpman et al. (2004).

Reassuringly, the coefficients of all different measures of the incidence of large firms confirm the positive impact on the internationalization index and are in line with the first hypothesis. Our main results on the productivity level are confirmed also. Moreover, as already mentioned in Section 4.2, the use of TFP as a measure of productivity implies Germany to be excluded from the analysis sample. For this reason, in the robustness checks reported in Table 10, we include this country and adopt as an alternative measure, the average level of labour productivity. Also in this case, the main results are confirmed. Compared to the impact of TFP reported in Table 5, productivity has a higher coefficient and a higher impact on the probability of internationalize with both exports and investment. The impact of remaining coefficients is almost unchanged. 
Table 9 - Robustness checks: different measures of the incidence of large firms

\begin{tabular}{|c|c|c|c|c|c|c|c|c|c|c|c|c|c|c|c|}
\hline & \multicolumn{5}{|c|}{$9^{\text {th }}$ and $10^{\text {th }}$ decile } & \multicolumn{5}{|c|}{$4^{\text {th }}$ and $5^{\text {th }}$ quintile } & \multicolumn{5}{|c|}{ Sales dispersion } \\
\hline & \multicolumn{2}{|c|}{ Coefficients } & \multicolumn{3}{|c|}{ Changes in predicted probability } & \multicolumn{2}{|c|}{ Coefficients } & \multicolumn{3}{|c|}{ Changes in predicted probability } & \multicolumn{2}{|c|}{ Coefficients } & \multicolumn{3}{|c|}{ Changes in predicted probability } \\
\hline & (1) & & $\begin{array}{r}\text { Domestic } \\
\text { (2) }\end{array}$ & $\begin{array}{r}\text { Export } \\
\text { (3) }\end{array}$ & $\begin{array}{r}\text { Export } \\
\text { and FDI } \\
(4)\end{array}$ & (5) & & $\begin{array}{r}\text { Domestic } \\
(6)\end{array}$ & $\begin{array}{r}\text { Export } \\
\text { (7) }\end{array}$ & $\begin{array}{r}\text { Export } \\
\text { and FDI } \\
(8)\end{array}$ & (9) & & $\begin{array}{r}\text { Domestic } \\
\text { (10) }\end{array}$ & $\begin{array}{r}\text { Export } \\
(11)\end{array}$ & $\begin{array}{r}\text { Export } \\
\text { and FDI } \\
(12)\end{array}$ \\
\hline$\overline{T F P^{a}}$ & $\begin{array}{r}1.204 \\
(0.028)\end{array}$ & **** & -0.088 & 0.021 & 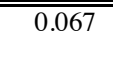 & $\begin{array}{r}1.179 \\
(0.028)\end{array}$ & $* * *$ & -0.085 & 0.020 & 0.065 & $\begin{array}{r}1.197 \\
(0.027)\end{array}$ & $* * *$ & -0.090 & 0.021 & 0.069 \\
\hline Num. of large firms $\left(9^{\text {th }} \text { decile }\right)^{b}$ & $\begin{array}{r}0.466) \\
(0.019)\end{array}$ & $* * *$ & -0.044 & 0.019 & 0.025 & & & & & & & & & & \\
\hline Num. of large firms $\left(10^{\text {h }} \text { decile }\right)^{b}$ & $\begin{array}{r}0.203 \\
(0.018)\end{array}$ & **** & -0.018 & 0.006 & 0.011 & & & & & & & & & & \\
\hline Num. of large firms $\left(4^{\text {th }} \text { quintile }\right)^{b}$ & & & & & & $\begin{array}{r}0.093 \\
(0.016)\end{array}$ & **** & -0.011 & 0.004 & 0.007 & & & & & \\
\hline Num. of large firms $\left(5^{\text {th }} \text { quintile }\right)^{b}$ & & & & & & $\begin{array}{r}0.533 \\
(0.015)\end{array}$ & **** & -0.076 & 0.035 & 0.041 & & & & & \\
\hline Sales dispersion $^{a}$ & & & & & & & & & & & $\begin{array}{r}0.209 \\
(0.013)\end{array}$ & **** & -0.018 & 0.005 & 0.013 \\
\hline Capital intensity ${ }^{a}$ & $\begin{array}{r}5.023 \\
(0.129)\end{array}$ & $* * *$ & -0.070 & 0.026 & 0.044 & $\begin{array}{r}5.175 \\
(0.131)\end{array}$ & **** & -0.072 & 0.026 & 0.046 & $\begin{array}{r}5.050 \\
(0.128)\end{array}$ & $* * *$ & -0.072 & 0.025 & 0.046 \\
\hline Patents $^{b}$ & $\begin{array}{r}0.110 \\
(0.010)\end{array}$ & $* * *$ & -0.011 & 0.004 & 0.007 & $\begin{array}{r}0.106 \\
(0.010)\end{array}$ & $* * *$ & -0.010 & 0.004 & 0.006 & $\begin{array}{r}0.195 \\
(0.009)\end{array}$ & $* * *$ & -0.020 & 0.008 & 0.012 \\
\hline Distance $^{a}$ & $\begin{array}{r}-0.464 \\
(0.012)\end{array}$ & $* * *$ & 0.034 & -0.013 & -0.020 & $\begin{array}{c}-0.467 \\
(0.012)\end{array}$ & **** & 0.034 & -0.013 & -0.020 & $\begin{array}{r}-0.458 \\
(0.012)\end{array}$ & $* * *$ & 0.034 & -0.013 & -0.021 \\
\hline Islands & $\begin{array}{r}0.850 \\
(0.035)\end{array}$ & $* * *$ & -0.118 & -0.076 & 0.194 & $\begin{array}{r}0.806 \\
(0.035)\end{array}$ & **** & -0.112 & -0.065 & 0.177 & $\begin{array}{r}0.923 \\
(0.035)\end{array}$ & **** & -0.130 & -0.099 & 0.228 \\
\hline Common language & $\begin{array}{r}0.421 \\
(0.028)\end{array}$ & $* * *$ & -0.035 & 0.002 & 0.033 & $\begin{array}{r}0.425 \\
(0.028)\end{array}$ & **** & -0.035 & 0.002 & 0.033 & $\begin{array}{r}0.403 \\
(0.027)\end{array}$ & **** & -0.035 & 0.002 & 0.033 \\
\hline Common religion & $\begin{array}{r}0.343 \\
(0.037)\end{array}$ & $* * *$ & -0.031 & 0.005 & 0.026 & $\begin{array}{r}0.379 \\
(0.037)\end{array}$ & **** & -0.033 & 0.005 & 0.028 & $\begin{array}{r}0.306 \\
(0.037)\end{array}$ & $* * *$ & -0.028 & 0.005 & 0.023 \\
\hline Tariffs & $\begin{array}{r}-0.311 \\
(0.135)\end{array}$ & $* *$ & 0.004 & -0.001 & -0.003 & $\begin{array}{r}-0.318 \\
(0.136)\end{array}$ & ** & 0.004 & -0.001 & -0.003 & $\begin{array}{r}-0.368 \\
(0.133)\end{array}$ & $* * *$ & 0.005 & -0.001 & -0.003 \\
\hline Common partners in trade ${ }^{b}$ & $\begin{array}{r}0.353 \\
(0.017)\end{array}$ & $* * *$ & -0.039 & 0.008 & 0.031 & $\begin{array}{r}0.350 \\
(0.017)\end{array}$ & **** & -0.038 & 0.008 & 0.030 & $\begin{array}{r}0.340 \\
(0.017)\end{array}$ & $* * *$ & -0.039 & 0.008 & 0.031 \\
\hline Common partners in $F D I^{b}$ & $\begin{array}{r}0.866 \\
(0.020) \\
\end{array}$ & $* * *$ & -0.085 & 0.028 & 0.057 & $\begin{array}{r}0.842 \\
(0.020) \\
\end{array}$ & $* * *$ & -0.082 & 0.026 & 0.055 & $\begin{array}{r}0.937 \\
(0.020) \\
\end{array}$ & $* * *$ & -0.094 & 0.030 & 0.064 \\
\hline $\begin{array}{l}\text { cut1 } \\
\text { cut } 2\end{array}$ & $\begin{array}{r}5.559 \\
(0.217) \\
10.091 \\
(0.225) \\
\end{array}$ & $\begin{array}{l}* * * \\
* * *\end{array}$ & & & & $\begin{array}{r}5.570 \\
(0.217) \\
10.145 \\
(0.225) \\
\end{array}$ & $\begin{array}{l}* * * \\
* * * \\
* * *\end{array}$ & & & & $\begin{array}{r}5.399 \\
(0.213) \\
9.836 \\
(0.220) \\
\end{array}$ & $\begin{array}{l}* * * \\
* * *\end{array}$ & & & \\
\hline Average predicted probability & & & 0.087 & 0.856 & 0.058 & & & 0.087 & 0.855 & 0.058 & & & \begin{tabular}{ll|l}
0.086 \\
\end{tabular} & 0.856 & 0.058 \\
\hline Observations & & & 67,975 & & & & & 67,975 & & & & & 67,896 & & \\
\hline
\end{tabular}

Variables description and sources are provided in Table 1. Columns (1),(5) and (9) report coefficient of estimations. Columns (2)-(4), (6)-(8) and (10)-(12) report changes in predicted probability for continuous variables or dummies varying from $25^{\text {th }}$ to $75^{\text {th }}$ of the world distribution, for discrete variables varying from the minimum to the maximum value and marginal effects for "Common partners in FDI". cut1 and cut 2 indicate thresholds between one category and the next. Standard errors robust to heterosckedasticity are reported in parentheses. Standard errors for cut points are calculated with the delta method. ***,** and * indicate statistical significance at the $1 \%, 5 \%$ and $10 \%$ level, respectively.

${ }^{\text {a }}$ This variable is included as $\ln ($ variable).

${ }^{\mathrm{b}}$ This variable is included as $\ln (1+$ variable $)$. 
Table 10 - Robustness checks: labour productivity

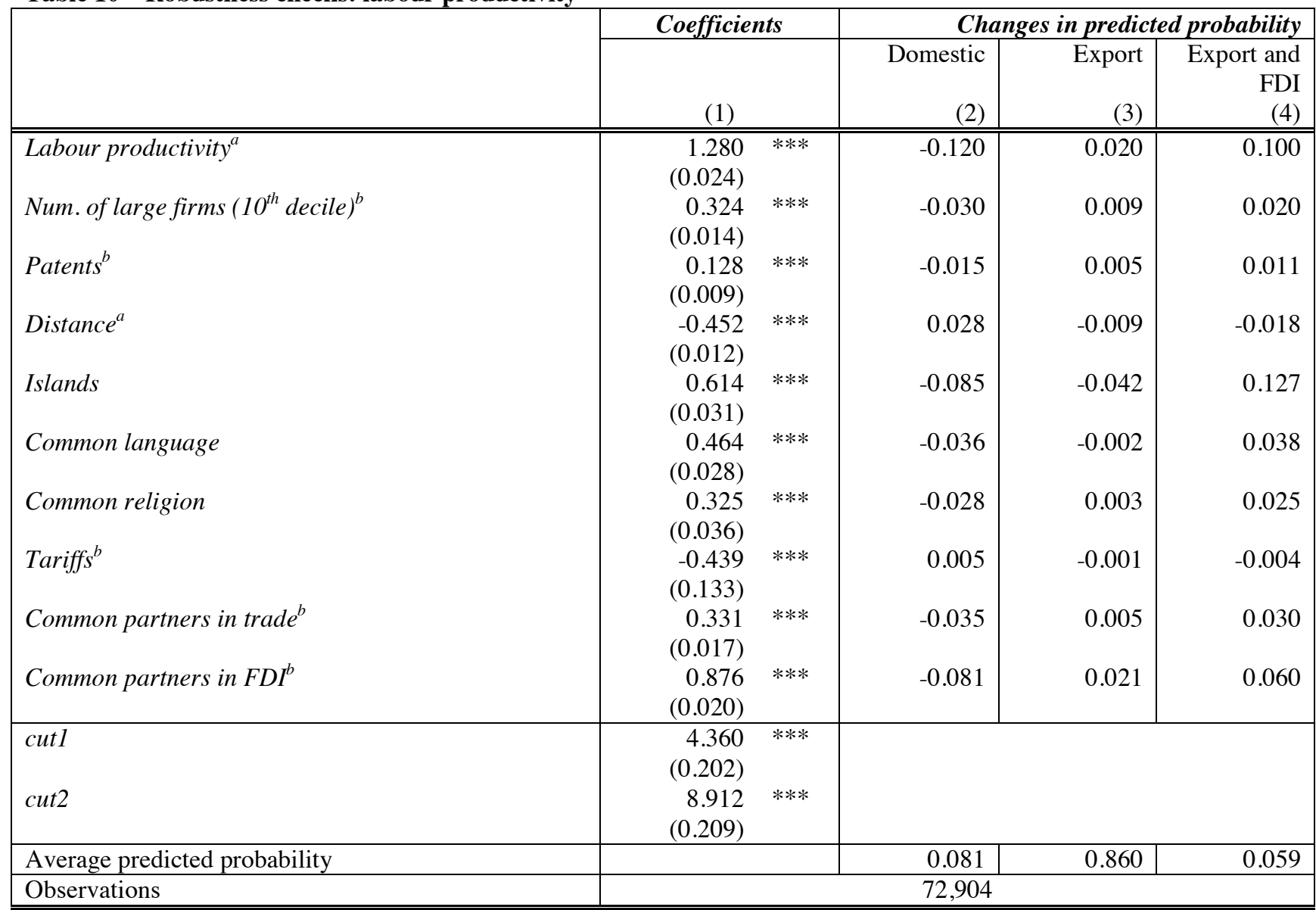

Variables description and sources are provided in Table 1. Column (1) reports coefficient of estimations. Columns (2)-(4) report changes in predicted probability for continuous variables varying from $25^{\text {th }}$ to $75^{\text {th }}$ of the world distribution, for discrete variables or dummies varying from the minimum to the maximum value and marginal effects for "Common partners in FDI". cutl and cut 2 indicate thresholds between one category and the next. Standard errors robust to heterosckedasticity are reported in parentheses. Standard errors for cut points are calculated with the delta method. ***,** and $*$ indicate statistical significance at the $1 \%, 5 \%$ and $10 \%$ level, respectively.

${ }^{a}$ This variable is included as $\ln ($ variable).

${ }^{\mathrm{b}}$ This variable is included as $\ln (1+$ variable $)$. 


\section{Conclusions}

The literature studying firms' choice between exporting at arms' length and serving foreign market through FDI, traditionally modeled as a proximity-concentration trade-off (Brainard 1993, 1997), has been enriched by more recent empirical contributions taking into account heterogeneity in firm productivity (Yeaple 2003; Helpman et al. 2004; Oldenski 2010). In particular, Helpman et al. (2004), building on the theoretical framework of Melitz (2003), demonstrate that a wider dispersion of firms size - reflecting high productivity level - within each sector is associated with a higher incidence of foreign affiliates' sales relative to exports. However, in the existing literature, the distinction between the impact of firm size and firm productivity in the modes of exports is often blurred. In addition, while generating important insights, these studies have generally focused on single-country analysis.

In this paper we analyse the relationship between country and sector characteristics and different internationalization strategies (i.e. export and the FDI), paying special attention to the role of both productivity and the distribution of firms by size in a sector. In particular, we make the hypotheses that a higher productivity level and a distribution of firms by size shifted toward large firms are associated with a higher level of foreign expansion along the extensive margin, with a stronger effect on FDI than on exports.

From a methodological point of view, we adopt an ordered-choice model. More importantly, we go beyond country studies to look for general patterns. In point of fact, we enlarge previous empirical analyses using a large dataset including 24 domestic countries, 91 foreign countries and 57 manufacturing industries between 1994 and 2004.

The results obtained from the whole sample of countries are qualitatively consistent with the hypotheses that more productive sectors internationalize and that sectors characterized by a distribution of firms by size shifted toward large firms are more likely to be able to afford the higher fixed costs required to serve foreign consumers. These results are also consistent with the theoretical model of Helpman et al. (2004) suggesting that larger and more productive firms should be more likely to internationalize through foreign investment.

Provided that multinational enterprises have increasingly considered developing countries as profitable investment locations, we obtain that for sector in developed countries internationalizing toward these countries both productivity and distribution of firms by size matter. On the other hand, sectors in developed countries going to other developed countries do not need to be more productive, 
but they need to be large. Finally, our results are also robust to different measures of the number of large firms and the productivity in a sector.

In this paper, the decision of firms on how to serve foreign markets is at issue. We provide empirical evidence for the determining country and sector characteristics (such as productivity and firms size)fixed plant setup costs) of this strategy choice. The above results confirm the theoretical insights suggesting that sectors with higher level of productivity and a distribution of firms shifted toward large firm not only tend to internationalize more, but also to prefer more commitment by adding investment abroad to exports. Consequently, it would be self-defeating if governments gave less priority to promote internationalization: this may deter the improvement of firm productivity and hamper economic growth.

\section{Acknowledgment}

We would like to acknowledge the comments of participants at the Italian Trade Study Group conference held in Catania, 15-16 June 2012, and at the European Trade Study Group conference held in Leuven, 13-15 September 2012. In particular, we wish to thank Maurizio Zanardi and Filippo Vergara Caffarelli for helpful comments on a previous version of this paper. A special thanks to the Electronic Resources Area of Bocconi University's library for providing the access to the Worldscope Database. 


\section{References}

Barba Navaretti, G., \& Venables, A. J. (2004). Multinational firms in the world economy. Princeton: Princeton University Press.

Basile, R., Giunta, A., \& Nugent, J. (2003). Foreign expansion by Italian manufacturing firms in the nineties: an ordered probit analysis. Review of Industrial Organization, 23(1), 1-24.

Benfratello, L., \& Razzolini, T. (2009). Firms' productivity and internationalisation choices: evidence for a large sample of manufacturing firms. In L. Piscitello, \& G. Santangelo (Eds.), Multinationals and local competitiveness. Milano: Franco Angeli.

Bernanke, B. S., \& Gurkaynak, R. S. (2002). Is growth exogenous? Taking Mankiw, Romer and Weil seriously. In B. S. Bernanke, \& K. Rogoff (Eds.), NBER Macroeconomics annual 2001 (pp. 1157). Cambridge, MA: MIT Press.

Bernard, A. B., Jensen, J. B, \& Lawrence, R. Z. (1995). Exporters, jobs, and wages in U.S. Manufacturing: 1976-1987. Brookings Papers on Economic Activity, Microeconomics, 1995(1995), 67-119.

Bernard, A. B. \& Jensen, J. B. (2004). Why some firms export?. The Review of Economics and Statistics, 86(2), 561-569.

Bernard, A. B., Jensen, J. B., Redding, S. \& Schott, P. K. (2007). Firms in international trade. Journal of Economic Perspectives, 21(3), 105-130.

Blonigen, B. (2005). A review of the empirical literature on FDI determinants. Atlantic Economic Journal, 33, 383-403.

Brakman, S., Garretsen, H., \& Van Marrewjk, C. (2005). Cross-border mergers and acquisitions: on revealed comparative advantage and merger waves. CESifo Working Paper n. 1602. http://www.SSRN.com/abstract=870389. Accessed 3 March 2010.

Brainard, S. L. (1993). A simple theory of multinational corporations and trade with a trade-off between proximity and concentration. NBER Working Paper n. 4269. http://www.nber.org/papers/w4269. Accessed 3 March 2010.

Brainard, S. L. (1997). An empirical assessment of the proximity-concentration trade-off between multinational sales and trade. American Economic Review, 87(4), 520-544.

Bougheas, S., \& Gorg, H. (2008). Organizational forms for global engagement of firms. University of Nottingham, GEP Research Paper 2008/33. http://ssrn.com/abstract=1448554. Accessed 27 February 2012.

Calia, P., \& Ferrante, M. R. (2010). How do firms combine different internationalization modes? A multivariate probit approach. Paper presented at the ETSG 2010 Annual Conference, 9-11 Septembe 2010, Lausanne, Switzerland. http://www .etsg.org/ETSG2010/ETSG2010Programme.html. Accessed 14 February 2012.

Carr, D. L., Markusen, J. R., \& Maskus, K. E. (2001). Estimating the knowledge capital model of the multinational enterprises. American Economic Review, 91(3), 693-708.

Castellani, D., \& Zanfei, A. (2007). Internationalisation, innovation and productivity: how do firms differ in Italy. The World Economy, 30(1), 156-176.

Chaney, T. (2011). The network structure of international trade. NBER Working Paper n. 16753. http://www .nber.org/papers/w16753. Accessed on 14 February 2012. 
Disdier, A. C., \& Head, K. (2008). The puzzling persistence of the distance effect on bilateral trade. The Review of Economics and Statistics, 90(1), 37-48.

Engel, D., Procher V., \& Schmidt, C. M. (2009). Foreign market dynamics and the symmetric role of firm-specific characteristics - evidence for French firms. Mimeo.

Felbermayr, G.J., \& Kohler, W. (2006). Exploring the intensive and extensive margins of world trade. Review of World Economics/Weltwirtschaftliches Archiv, 142(4), 642-674.

Francois, J. (2010). Who trades with whom. Paper presented at the $12^{\text {th }}$ European Trade Study Group, Lausanne 9-11 September.

Greene, W. H. (2008). Econometric Analysis. Upper Saddle River, New Jersey: Pearson Education.

Greenaway, J. \& Kneller, J. (2007). Firm heterogeneity, exporting and foreign direct investment. The Economic Journal, 117(517), F134-F161.

Head, K., \& Ries, J. (2003). Heterogeneity and the FDI versus export decisions of Japanese manufacturers. Journal of Japanese International Economies, 17(4), 448-467.

Helpman, E., Melitz, M. J., \& Yeaple, S. R. (2004). Export versus FDI with heterogeneous firms. American Economic Review, 94(1), 300-16.

Helpman, E., Melitz, M. J., \& Rubistein, Y. (2008). Estimating trade flows: trading partners and trading volumes. The Quarterly Journal of Economics, 73(2), 441-487.

Herger N., Kostoggiannis, C., \& McCorriston, S. (2008). Cross-border acquisitions in the global food sector. European Review of Agricultural Economics, 35(4), 563-587.

Isaksson, A. (2009). The UNIDO world productivity database: an overview. International Productivity Monitor, 18(1), 38-50.

Johnson, D. K. N. (2002). The OECD technology concordance (OTC): patents by industry of manufacture and sector of use. OECD Science, Technology and Industry Working Papers 2002/5. http://www .oecd-ilibrary.org/science-and-technology/the-oecd-technology-concordanceotc_521138670407. Accessed 14 February 2012.

Kimura, F., \& Kiyota, K. (2006). Exports, FDI, and productivity: dynamic evidence from Japanese firms. Review of World Economics/Weltwirtschaftliches Archiv, 142(4), 695-719.

Markusen, J. R., \& Maskus, K. (2002). Discriminate among alternative theories of the multinational enterprise. Review of International Economics, 10(4), 694-707.

Martins, P. S., \& Yang, Y. (2009). The impact of exporting on firm productivity: a meta-analysis of the learning-by-exporting hypothesis. Review of World Economics/Weltwirtschaftliches Archiv, 145(3), 431-445.

Melitz, M. J. (2003). The impact of trade on intra-industry reallocation and aggregate industry productivity. Econometrica, 71(6), 1695-1725.

Mood, C. (2010). Logistic regression: why we cannot do what we think we can do, and what we can do about it. European Sociological Review, 26(1), 67-82.

Nunnenkamp, P. (2002). Determinants of FDI in developing countries: has globalization changed the rules of the game?. Kieler Arbeitspapiere, n. 1122, http://hdl.handle.net/10419/2797. Accessed 20 November 2012.

Oberhofer, H., \& Pfaffermayr, M. (2012). FDI versus exports: multiple host countries and empirical evidence. The World Economy, 35(3), 316-330. 
Oldenski, L. (2010). Export versus FDI: a task based approach. Working Paper, Georgetown University. http://www9.georgetown.edu/faculty/lo36/Oldenski_XvsFDI_Nov2010.pdf. Accessed 14 February 2010.

Pietrovito, F., Pozzolo, A. F, \& Salvatici, L. (2013). Exports vs FDI: evidence from cross-country industry data. In: S. Beugelsdijk, S. Brakman, H. van Ees, \& H. Garretsen (Eds.), Firms in the international economy. Closing the gap between international economics and international business. MIT Press (forthcoming).

Slangen, A. H. L., \& Beugelsdijk, S. (2010). The impact of institutional hazards on foreign multinational activity: A contingency perspective. Journal of International Business Studies, 41, 980-995.

Slangen, A. H. L., Beugelsdijk, S., \& Hennart, J. M. A. (2011) The impact of cultural distance on bilateral arm's length exports: an international business perspective. Management International Review, 51(6), 875-896.

Sosa, A. M., Nunnenkamp, P., Busse, M. (2012). What drives FDI from non-traditional sources? A comparative analysis of the determinants of bilateral FDI flows. HWWI research paper, no. 114, http://hdl.handle.net/10419/55224. Accessed on 21 January 2013.

Taylor, M. P., \& Sarno, L. (1997). Capital flows to developing countries: long-and short-term determinants. The World Bank Economic Review, 11(3), 451-470.

Todo, Y. (2011). Quantitative evaluation of the determinants of exports and FDI: firm-level evidence from Japan. The World Economy, 34(3), 355-381.

UNCTAD (1996). World Investment Report 1996. United Nations, New York. http://unctad.org/en/Docs/wir1996_en.pdf. Accessed 20 March 2010.

Wang, C., Wei, Y., \& Liu, X. (2010). Determinants of bilateral trade flows in OECD countries: evidence from gravity panel data models. The World Economy, 33(7), 894-915.

Wooldridge J. M. (2010). Econometric analysis of cross section and panel data. Cambridge, MA: MIT Press.

Yeaple, S. (2003). The role of skill endowments in the structure of US outward foreign investments. Review of Economics and Statistics, 85(3), 726-734. 